\title{
An Analysis of Research Trends of Master's Thesis and Doctoral Dissertations in Audiology: A Review of Research from 1999 to 2014
}

\author{
Mi Sook Lee', Yong Gyu Seo² \\ ${ }^{1}$ Jeeum Auditory Rehabilitation Center, Daegu, Korea \\ ${ }^{2}$ Department of Speech-Language Pathology \& Audiology, Kaya University, Gimhae, Korea
}

\author{
청각학 관련 국내연구동향 분석: 1999 2014년 학위논문을 중심으로 \\ 이 미 숙'서 용 $^{2}$ \\ 지음청각언어연구소 ${ }^{1}$, 가야대학교 언어치료 청각학과 ${ }^{2}$
}

\begin{abstract}
Purpose: This study aimed to offer the preliminary data on research trends of audiology and to suggest graduate students and researchers in audiology, while suggesting a better direction of research. Methods: A total of 228 thesis for masters' degree and dissertation for doctoral degree on audiology from 1999 to 2014 that selected from a legal deposit National Library in Korea were analyzed in terms of method, subjects, and topics of research. Results: First of all, the largest number of the studies were conducted during the period from 2007 to 2010. Second, the methodology of researches was experimental study (83.3\%), survey study (11.3\%) and case study (2.4\%). As we expected, an experimental study was most of all. Third, the range of academic interests and approaching efforts toward audiology had been expanded to various areas including aural rehabilitation, hearing assessment, amplification, auditory processing disorder, vestibular, tinnitus, hearing management, hearing conservation. However, most of the topics were related to hearing assessment. Finally, the research subjects were related to adults in general. Conclusion: The findings of this study provide the opportunities to show new light on the current status of master's thesis and doctoral dissertation and to deliberate on the future research direction of audiology in Korea.
\end{abstract}

Key Words: Audiology, Research trends, Methodology of researches.

Received: June 14, 2016 / Revised: August 1, 2016 / Accepted: September 15, 2016

Correspondence: Yong Gyu Seo, Department of Speech-Language Pathology \& Audiology, Kaya University, 208 Samgye-ro, Gimhae 50830, Korea

Tel: +82-55-330-1155 / Fax: +82-55-322-4735 / E-mail: kayazi@korea.com

\section{INTRODUCTION}

장애인 실태조사는 복지법에 근거하여 장애인의 정의를 "신 체적 정신적 장애로 오랫동안 일상생활이나 사회생활에서 상 당한 제약을 받는 자"로 15 개의 장애유형에 따라 접근하고 있 다. 이에 의하면 우리나라의 장애인 출현율은 $5.59 \%$ 로 인구 10,000 명 중 559 명이 장애인인 경우를 의미하며 2014년 12월 말 등록 장애인 수는 2,494,460명으로 나타났으며 이중 청각장 애인 인구의 경우 271,000 명이나 $27 \mathrm{~dB} \mathrm{HL}$ 이상의 청력손실을 보이는 경우 2015년 현 313,500명으로 추정된다(Kim et al., 2014). 특히 우리나라는 일본, 독일 이탈리아를 포함한 초 고령
화 국가 중의 하나로 노인인구의 비율이 2013년 전체 인구의 $12.2 \%$ 로 매년 증가하는 추세다. 65 세 이상 고령자가 차지하는 비율은 $12.2 \%$ 로 2008년 14.3\%에서 지속적으로 증가하여 2030 년 24.3\%, 2050년 37.4\% 수준에 이를 것으로 전망된다(Song \& Park, 2011). 고령화 사회의 급속한 진입은 노화와 관련하여 여 러 건강문제를 대두시키는데 관절염 다음으로 흔한 난청은 삶 의 질이 중요시되는 현대사회에서 더욱 관심이 증대될 것이다. 특히 우리나라 난청인 유병률에 대한 정확한 통계는 없으나 Lim et al.(2011)에 따르면 노인인구가 9\%일 때 노인성 난청의 비율은 65 75세의 경우 25 50\%, 75세 이상은 38 70\%에 이르 러 국내에서는 $1,700,000$ 명 이상의 환자가 있을 것이라고 추정 
하고 있다. 또한 신생아 난청 역시 출현율은 $0.1 ~ 0.3 \%$, 즉 1,000 명당 4명 정도로 출현하는 것으로 볼 수 있으며, 산업화로 인한 작업장의 소음은 직업성 질환 유소견자 중 가장 높은 비율을 차지해 2001년에는 1,330건으로 직업병 유소견자의 $55 \sim 5 \%$ 로 절반을 차지하고 있어(International Organization for Standardization, 2012) 난청인구의 증가를 더욱 더 가속화시킴에 따라 포괄적 의미의 가족 구성원 중 적어도 한 명은 난청을 가 지고 있다는 추측도 가능하다고 할 수 있다. 이러한 난청인구의 증가는 청각의료서비스, 청각케어서비스에 대한 수용 증가를 예 측할 수 있어 청각학에 대한 전문지식을 바탕으로 청능치료 공 공서비스 및 교육 연구를 수행하는 청각전문가의 역할이 중요해 졌다. 그러나 현재 늘어나고 있는 청각장애인의 수와 그에 따른 사회적 관심과 요구에 비하여 이를 중재해줄 수 있는 청각전문 가의 경우 전 세계적으로 15,000 20,000명의 청능사(audiologist)가 활동하고 있으며 인구 20,000 명당 한 명의 청능사가 필 요하다고 한다(ASHA, 2015). 이에 근거해 우리나라 인구를 45,000 만 명으로 가정한다면 약 2,000명 이상의 전문가가 필요 하나 현재 그 수는 절대적으로 부족한 형편이다. 따라서 복지 사회를 지향하는 현대사회에서 청각학의 중요성이 어느 때보 다 배증하리라 생각되며 시대적인 사명이라 해도 과언이 아닐 것이다.

본래 청각학(audiology)이란 난청으로부터 발생되는 청각 장 애를 학문적으로 연구하고 이를 토대로 청각 기능의 평가, 증 폭기기 그리고 청각재활을 임상을 통해서 제공하는 학문이다. 즉, 소리를 뜻하는 라틴어 "audire"와 학문을 뜻하는 그리스어 "logia"에서 유래되었고(Gelfand, 2009) 소리를 뜻하는 접두사 audi-와 학문을 뜻하는 접미사 - $\log y$ 가 합성된 단어로 청각과 청력손실에 관련된 학문을 뜻한다. 세계 제 2 차 대전 중 청력 손실자들은 미군 재활센터에서의 청력손실에 대한 재활서비 스에 만족하였고 청각학의 효과는 상당히 성공적이었다. 그러 한 결과가 전쟁 후에는 시민들을 위한 유사한 청각재활센터를 발생하게 하였고 이후 미국 내에서는 청각학이 기존의 hearing science나 이과학 외에도 언어병리학, 소아과학, 노년학, 특수교 육학 등 여러 학문 분야의 복합성을 발판으로 독립적이고 전문 적인 학문으로 발전하여(Katz, 2002; Martin \& Clark, 2003) 1945년에 대중적으로 쓰이기 시작했다. 그러나 그 용어에 대하 여 누가 처음에 사용하였는지는 알려지진 않았지만 60여 년이 지난 현재는 청력손실과 관계된 전문분야를 대표하는 용어로 자리 잡았다(Newby \& Popelka, 1992).

이렇듯 청각학의 태동은 역사적 배경과 주변 학문과의 연관 성에 따라서 각 나라마다 조금씩 다른 모습으로 발전되어 왔으 며, 여타의 선진국과 마찬가지로 국내의 청각학도 대중에게 널 리 알려지진 않았으나 60년 역사의 이비인후과학의 한 학문 분
야로서 발전되어 왔다. 그 시초는 1960년대 후반, 1969년에 언 어와 청각장애인들을 위한 "언어청각연구소"에 "언어교정실" 과 “청력검사실”을 둔 것으로 1960년대의 청각학은 특수교육과 청각장애교육 중심의 강의가 이루어졌을 뿐 학문적인 기반이 거의 없이 1970 80년대까지 계속되었다(Lee \& Chae, 2011). 그러나 1990년대 들어 보청기 및 인공와우 등 청각보조기기의 관심과 이를 통한 청각장애인들의 재활에 긍정적 평가가 알려 지면서 체계적인 학문의 필요성이 증대되었고 1997년 청각학 연구과정이, 그리고 이듬해 1998년에 교육부의 인가로 한림대 학교 사회복지대학원내에 국내 최초로 석사과정이 개설되어 제 도적으로 자리를 잡기 시작하였다. 그 이후 현재 전국 6개 대학 (한림대학교, 세한대학교(구 대불대학교), 남부대학교, 가야대학 교, 부산가톨릭대학교, 대구가톨릭대학교, 우송대학교)에 학부 수준의 청각학과가 개설되어 있으며 5개 대학(한림대학교, 한 림국제대학원대학교, 세한대학교 보건대학원, 남부대학교 보건 경영대학원, 대구가톨릭대학교 보건과학 대학원)에 석사과정 이, 2개 대학(한림대학교, 대구가톨릭대학교)에 박사과정이 개 설되어 매년 학부에서 약 100 명의 청각학 전공자가 배출되는 현황에 이르게 되었다. 이들은 전문적 지식을 바탕으로 대학이 나 연구소에서 강의와 연구를 하거나 청각장애를 다루는 기관 에서 청각장애진단과 재활 및 예방 등에 관한 업무를 담당함으 로써 사회적으로 중요한 역할을 담당하고 있다.

이처럼, 청각장애인의 증가에 따른 사회적 관심과 요구가 급 격히 확대되면서 청각전문가의 기반이 되는 청각학은 눈부신 발전을 거듭함에 따라 청각학 관련 석·박사 학위논문과 대한 청각학회지와 청능재활을 포함하는 정기간행 전문지에만 매년 수십 편의 연구논문이 지상 발표되고, 수권의 청각학 교과서의 발간 또한 해마다 발표되고 있다. 특히 학위논문의 경우는 주 제의 전문지식을 다루면서 기존의 학술이론을 비판, 수정, 확 장하는 차원에서 작성되므로 주제분야의 학문발전에 기여할 뿐만 아니라 질적으로도 우수한 연구논문이다. 게다가 학위논 문의 구성체제, 연구방법은 후속학문세대에게 중요한 연구모델 이 될 수 있어 큰 의의를 가진다. 따라서 학위논문의 연구동향 파악은 향후 해당학문과 관련한 연구과제에 대한 시사점을 탐 색하여 발전의 계기로 삼을 수 있다. 청각학 또한 학문으로 발 전뿐만 아니라 사회적으로 중요한 역할을 담당해오고 있으나 그 양적 증가에 비하여 단일학문으로서 경향을 분석한 연구는 전무한 형편이다. 단지 청각장애 분야 측면에서 교육적인 방법 론에 대한 관점에서 청각장애에 대한 수년간의 연구경향을 파 악하기 위한 국내연구들(Lee et al., 2004; Park \& Kim, 2001) 이 있거나 청각장애의 특성과 중재방법, 중재효과를 보고한 논 문(Kim, 2000; Ok, 2005)이 있을 뿐이다. 그러나 이들 연구들 은 교육대학원 혹은 특수교육대학원에서 청각장애를 전공한 
연구자들이 쓴 학위논문들을 분석한 것이므로 청각학의 경향 을 파악했다고 보기는 적합지 않다.

이에 본 연구는 국내외적으로 청각장애인이 증가 추세와 이 에 따른 사회적 관심과 요구가 급격히 확대되어 가고 있는 시점 에서 청각전문가의 기반이 되는 청각학을 전공으로 1999년부 터 2014년까지 15년간 발표된 학위논문을 분석하여 포괄적이 고 구체적인 경향을 파악함으로써 어떤 연구방법과 연구주제 들이 현장에서 적용되는지 연구동향을 알아보고 이를 바탕으 로 청각학과 관련된 연구과제에 대한 시사점에 접근하는 기초 자료를 제공하고자 하였다.

\section{MATERIALS AND METHODS}

\section{분석대상 논문 선정}

본 연구의 분석대상 논문은 국회전자도서관(http://www. nanet.go.kr), 한국교육학술정보서비스(http://www.riss.kr), 국 립중앙도서관(http://www.nl.go.kr), 한국학술정보(http:// www.kiss.kstudy.com) 등을 통해 검색된 석·박사 학위 논문 을 분석대상으로 하였다. 2014년 12월 기준 자료구분 영역 중 '학위논문' 창으로 제한하여 키워드는 〈청각학〉, 〈청각〉으로 1999 2014년까지 15년 동안의 자료를 검색한 결과 총358편(박 사: 35 석사: 323 )이었다. 이 중 주제는 청각이나 학위를 언어병 리학 또는 특수교육학 및 기타 학문으로 받은 학위논문을 배 제하였다. 연구목적인 〈청각학〉을 학위로 받은 논문의 연구동 향 탐색에 필요한 적정의 분석대상을 선정하기 위해 석사 및 박 사학위 과정이 개설되어 있는 학교[한림대, 남부대, 세한대(대 불대)]를 키워드로 연도별 각 논문을 하나씩 검색한 뒤 분석하 였다. 이 과정을 거쳐 최종 228편의 논문이 선정되었고 인터넷 상에서 직접 볼 수 있는 논문은 직접 출력하였고, 협정기관에 서 볼 수 있는 것은 대학도서관에서 출력하였으며, 그렇지 못한 논문은 국회도서관과 국립중앙도서관을 직접 방문하여 복사 의뢰하여 구입하거나 논문저자에게 직접 전달받았다.

\section{분석 지표}

청각학 학위논문의 연구경향을 살펴보기 위하여 박사 학위 논문 16편 석사 학위논문 212편, 총 228편의 논문에 대하여 연 구유형 및 연구주제, 연구대상 분석을 실시하였다. 분석 지표의 타당성은 청각학 박사 2 인의 검토를 거쳐 수정하였다. 연구유 형은 어떤 사실을 발견하거나 확인하기 위해 과학적인 방법을 사용하여 현상에 관한 지식을 탐구하는 일을 근거로 교육연구 방법에서 일반적으로 사용되는 기준근거(Seong, 1998)를 준거 로 하여 문헌연구, 실험연구, 조사연구, 사례연구(또는 면접), 기 타연구의 5 가지를 유형으로 삼았다. 실험, 조사, 사례연구는 명
확한 연구대상이 있었으므로 각각의 연구에서 대상자에 근거 하여 분석하였고 기타에 속한 연구들은 소수의 연구들로 도구 개발연구, 발달연구를 포함시켰다. 연구대상은 생애주기별로 분류하여 영유아(만 0 3세), 학령전기 아동(만 4 7세), 학령기 아동(만 8 18세), 성인(만 19 64세) 및 노인(만 65세 이상)으로 세분화하였으며, 두 대상군을 대상으로 연구한 경우 각 대상군 에 포함시켜 분석하였다. 그러나 연구대상이 구체적으로 제시 되지 않는 경우 혹은 연구대상이 전 계층을 아우르는 경우는 기타로 분석하였다. 특히, 연구대상이 명확히 기술되는 실험연 구, 조사연구의 경우 대상자(기준집단)에 근거하여 분류하였다. 연구주제에 따른 분석은 2013년 국가직무능력표준(national competency standard)의 〈청각관리〉 분야와 American Speech-Language-Hearing Association (ASHA)의 〈청각학〉, 미 국대학의 청각학 프로그램을 조사 분석한 Goulios(2010)의 <comparative audiology and development of a seeding model for affordable and sustainable audiolody education〉를 참 조하여 청력평가(hearing assessment), 증폭기기(amplification), 청능재활(audiologic rehabilitation), 중추청각처리장애 (auditory processing disorder), 전정(vestibular), 이명(tinnitus), 청각관리(hearing management), 청력보존(hearing conservation) 및 기타(etc)로 분류하였으며 각 주제별 세분화된 내용은 다음과 같다(Table 1). 자료의 분석은 SPSS (ver. 18.0, IBM Co., Chicago, IL, USA)을 이용하여 분석대상의 빈도와 백분율을 계산하였다.

\section{RESULTS}

\section{전체논문 분석}

1999 2014년까지 석사 학위논문 212편 박사 학위논문 16편 총 228편이 발표되었으며 연도별 논문편수를 보면 다음과 같다 (Table 1).

석사 학위논문의 경우 2008년에 석사 학위과정이 개설되고 첫 졸업생을 배출한 2000년 13편의 첫 학위논문이 발표된 이 래 매년 최소 7편 최대 22편까지 발표되며 평균 14편정도 발표 되고 있다. 석사 학위논문의 경우 2009 2012년은 논문 발표가 가장 활발한 시기로 전체 212편의 논문 중 76편(35.8\%)의 논문 이 발표되었고 박사 학위논문은 매년 1 2편씩 꾸준히 발표되 고 있으며 석사 학위논문과 마찬가지로 2009 2013년까지 논 문 발표가 가장 활발하였다(Table 1).

\section{연구유형에 따른 분석결과}

석·박사 학위논문 전체의 연구유형별 경향을 살펴보면(Figure 1) 처치, 자극 환경조건을 의도적으로 조작 혹은 통제하여 
Table 1. The classification of research area

\begin{tabular}{ll}
\hline \multicolumn{1}{c}{ Research area } & The details \\
\hline $\begin{array}{l}\text { Hearing assessment } \\
\text { Amplification }\end{array}$ & $\begin{array}{c}\text { Audiologic evaluation-Behavioral, Audiologic evaluation-Physiological } \\
\text { Hearing aids, Programming hearing aids, Cochlear implants, Device verification and } \\
\text { validation. }\end{array}$ \\
Aural Rehabilitation/Intervention & $\begin{array}{c}\text { Auditory training, Speech reading, Speech perception training, } \\
\text { Communication training }\end{array}$ \\
Auditory processing disorders & Assessment and management of auditory processing disorders and rehabilitation \\
Vestibular & Assessment and management of vestibular \\
Tinnitus & Assessment and management of tinnitus \\
Hearing Management & Development of auditory training tool, Education of hearing management, \\
Aural rehabilitation strategy & Acoustic characteristics, Auditory perception processing \\
Manchoacoustics & Noise measurement, Hearing protection, Device fitting, Hearing conservation program \\
conservation program & \\
Etc &
\end{tabular}

Table 2. The number of presented audiology master's thesis and doctoral dissertation by year $(n=228)$

\begin{tabular}{|c|c|c|c|c|c|c|}
\hline \multirow{2}{*}{ Year } & \multicolumn{2}{|c|}{ Master's thesis } & \multicolumn{2}{|c|}{ Doctoral dissertation } & \multicolumn{2}{|l|}{ Total } \\
\hline & Number of paper & $\%$ & Number of paper & $\%$ & Number of paper & $\%$ \\
\hline 2000 & 13 & 6.1 & & & 13 & 5.7 \\
\hline 2001 & 11 & 5.2 & & & 11 & 4.8 \\
\hline 2002 & 14 & 6.6 & & & 14 & 6.2 \\
\hline 2003 & 7 & 3.3 & & & 7 & 3.1 \\
\hline 2004 & 7 & 3.3 & & & 7 & 3.1 \\
\hline 2005 & 15 & 7.1 & 1 & 6.25 & 16 & 7.0 \\
\hline 2006 & 14 & 6.6 & 2 & 12.5 & 16 & 7.0 \\
\hline 2007 & 13 & 6.1 & 0 & 0 & 13 & 5.7 \\
\hline 2008 & 14 & 6.6 & 0 & 0 & 14 & 6.2 \\
\hline 2009 & 22 & 10.4 & 2 & 12.5 & 24 & 10.6 \\
\hline 2010 & 19 & 9.0 & 3 & 18.8 & 22 & 9.7 \\
\hline 2011 & 17 & 8.0 & 2 & 12.5 & 19 & 8.4 \\
\hline 2012 & 16 & 7.5 & 3 & 18.8 & 19 & 8.4 \\
\hline 2013 & 12 & 5.7 & 2 & 12.5 & 14 & 6.2 \\
\hline 2014 & 18 & 8.5 & 1 & 6.25 & 18 & 7.9 \\
\hline Total & 212 & 100 & 16 & 100 & 228 & 100 \\
\hline
\end{tabular}

변화를 알아보고자 한 실험연구가 192편(83.3\%)으로 가장 많 았다. 다음으로 조사연구 23편(11.3\%), 사례연구 7편(2.4\%) 순 으로 실험연구가 주를 이루었다.

연도별 연구유형에 따른 논문 분석결과 석사 학위논문의 경 우 179편(84.4\%)로 실험연구가 주를 이루고 있으며 조사연구는 24편(11.8\%)으로 매년 1 2편씩 발표되었으나 2012년 이후 증가 와 감소를 반복하고 있다. 사례연구는 5편(2.4\%)으로 2010년 첫 학위논문이 발표되었고 매년 1편씩 발표되고 있다. 박사 학 위논문 역시 실험연구의 비율이 13편(81.3\%)의 비율로 높게 나 타났고 조사연구의 경우 2편(12.5\%)으로 그 다음을 차지하였 다. 석·박사 학위논문 모두 실험연구의 비율이 높았으며 문헌 연구는 나타나지 않았다(Table 3).

\section{연구주제에 따른 분석결과}

연구주제에 대한 분석결과 10 개 분야와 관련지어 다양한 주 제의 연구가 이루어져왔으며 지난 15 년간 세부 연구주제를 빈 도순으로 정리한 표는 Table 4와 같다. 이들 연구주제는 석사 학위논문의 경우 2005년까지 청력평가, 증폭기기, 중추청각처 리장애, 청각관리, 심리음향 등 4 5개의 주제를 중심으로 한 연구가 이루어져 왔으나 2006년 이후부터는 청능재활전정, 이 명, 청력보존 등 7 8개의 주제영역까지 확장되어 연구주제가 다양해짐을 알 수 있다. 연구 빈도의 경우 박사 학위논문의 경 우 중추신경성 난청 관련 연구 그리고 심리음향에 관한 연구가 각각 4편과 8편으로 전체연구의 $50 \%$ 를 차지하였고 뒤를 이어 증폭기 관련 연구 3편(18.8\%), 청력평가와 관련된 연구(12.5\%) 


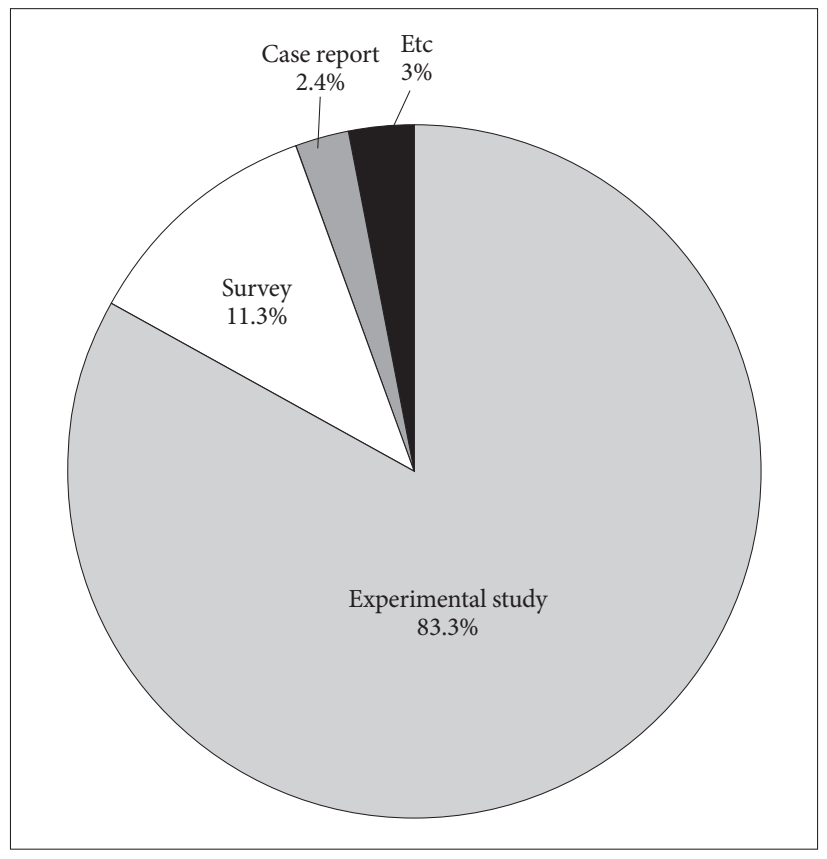

Figure 1. The classification of research methods.
가 그 뒤를 따랐다. 석사논문의 경우는 박사 학위논문과는 달 리 청각평가 관련 연구가 총 92편으로 전체 학위논문의 $43.5 \%$ 를 차지하였으며, 중추청각기능 평가 및 재활관련 연구는 22편 (10.3\%)으로 나타났다. 특히, 청력평가와 관련된 92편의 논문 중 36편(56\%)이 전기생리기능을 평가하는 논문으로 청성유발 전위(auditory evoked potential)와 관련된 연구는 24편(66.7\%), 이음향방사(otoacoustic emission, $\mathrm{OAE}$ )와 관련된 연구는 12 편(33.3\%)으로 나타났다(Figure 2). 보청기 및 인공와우를 포 함한 특수보청기의 적합과 평가를 포함하는 증폭기 관련 연 구는 33편(15.4\%), 이명 및 전정기능평가 및 재활에 관련된 연 구는 동일하게 11편(5.14\%)으로 나타났다. 그리고 청능훈련 평 가 와 도구개발이 주를 이룬 청각관리 및 연구 분야 그리고 심리음향에 관한 연구가 그 뒤를 이뤄 각각 15편(7.0\%), 12편 (5.60\%)으로 나타났다. 특히, 청능평가 도구개발에 관한 연구 는 2004년까지 매년 1, 2편의 논문이 발표되어 활발한 연구경 향을 보였으나 이후 등장하지 않고 있다. 이들 연구들은 어음 인지검사도구의 개발과 관련된 연구가 4편으로 가장 많았고 노

Table 3. The classification of research methods by year

\begin{tabular}{|c|c|c|c|c|c|c|c|c|c|c|c|c|c|c|c|c|}
\hline Degree & Methods & 00 & 01 & 02 & 03 & 04 & 05 & 06 & 07 & 08 & 09 & 10 & 11 & 12 & 13 & 14 \\
\hline \multirow[t]{6}{*}{ Master's thesis } & Experimental study & 11 & 11 & 12 & 6 & 4 & 14 & 11 & 12 & 10 & 20 & 16 & 16 & 12 & 10 & 12 \\
\hline & Survey study & 2 & 0 & 1 & 1 & 1 & 1 & 2 & 1 & 2 & 2 & 2 & 1 & 3 & 1 & 4 \\
\hline & Literature review & & & & & & & & & & & & & & & \\
\hline & Case study & & & & & & & & & & & 1 & & 1 & 1 & 2 \\
\hline & Etc & & & 1 & & 2 & & 1 & & 2 & & & & & & \\
\hline & Total & 13 & 11 & 14 & 7 & 7 & 15 & 14 & 13 & 14 & 22 & 19 & 17 & 16 & 12 & 18 \\
\hline \multirow{6}{*}{$\begin{array}{l}\text { Doctoral } \\
\text { dissertation }\end{array}$} & Experimental study & & & & & & 1 & 2 & & & 2 & 1 & 2 & 2 & 2 & 1 \\
\hline & Survey study & & & & & & & & & & & & & & & \\
\hline & Literature review & & & & & & & & & & & & & & & \\
\hline & Case study & & & & & & & & & & & 2 & 1 & & & \\
\hline & Etc & & & & & & & & & & & & & & & \\
\hline & Total & & & & & & 1 & 2 & & & 2 & 3 & 3 & 2 & 2 & 1 \\
\hline
\end{tabular}

Table 4. The classifications of research objects $(n=228)$

\begin{tabular}{lcccccccccccccccc}
\hline & 00 & 01 & 02 & 03 & 04 & 05 & 06 & 07 & 08 & 09 & 10 & 11 & 12 & 13 & 14 & Total \\
\hline Hearing assessment & 7 & 7 & 9 & 4 & 3 & $8(1)$ & 5 & 9 & 7 & $7(1)$ & 7 & 6 & 5 & 3 & 5 & $92(43.4)$ \\
Amplification & 3 & 2 & 3 & 1 & 1 & 34 & $2(1)$ & 1 & 1 & 6 & $3(1)$ & 2 & 2 & $0(1)$ & 2 & $32(15.1)$ \\
Aural rehabilitation & 0 & 0 & 0 & 0 & 0 & 0 & 0 & 0 & 0 & 0 & 0 & $0(1)$ & 1 & 2 & 2 & $5(2.4)$ \\
Auditory processing disorder & 0 & 0 & 0 & 0 & 1 & 1 & 1 & 1 & 1 & 3 & 2 & 4 & $3(2)$ & $3(1)$ & $2(1)$ & $22(10.4)$ \\
Vestibular & 0 & 0 & 0 & 0 & 0 & 0 & $2(1)$ & 1 & 1 & 3 & 2 & 1 & 1 & 0 & 0 & $11(5.2)$ \\
Tinnitus management & 0 & 0 & 0 & 0 & 0 & 0 & 1 & 0 & 0 & 1 & 1 & 1 & 2 & 2 & 3 & $11(5.2)$ \\
Hearing management & 0 & 1 & 2 & 2 & 2 & 1 & 1 & 0 & 1 & 1 & $2(1)$ & 1 & 0 & 0 & 1 & $15(7.1)$ \\
Psychoacoustics & 2 & 0 & 0 & 0 & 0 & 1 & 2 & 1 & 3 & $0(1)$ & $0(1)$ & $1(1)$ & $0(1)$ & 0 & 0 & $8(3.8)$ \\
Noise management and hearing & 0 & 0 & 0 & 0 & 0 & 0 & 0 & 0 & 0 & 1 & 2 & 2 & 2 & 2 & 3 & $12(5.7)$ \\
$\quad$ conservation program & & & & & & & & & & & & & & \\
Etc & 1 & 1 & 0 & 0 & 0 & 0 & 0 & 0 & 0 & 0 & 0 & 0 & 0 & 1 & 1 & $4(1.9)$ \\
Total & 13 & 11 & 14 & 7 & 7 & $15(1)$ & $14(2)$ & 13 & 14 & $22(2)$ & $19(3)$ & $17(2)$ & $17(3)$ & $12(2)$ & $18(1)$ & $212(100)$ \\
\hline Par
\end{tabular}

Parenthesis is percentage 


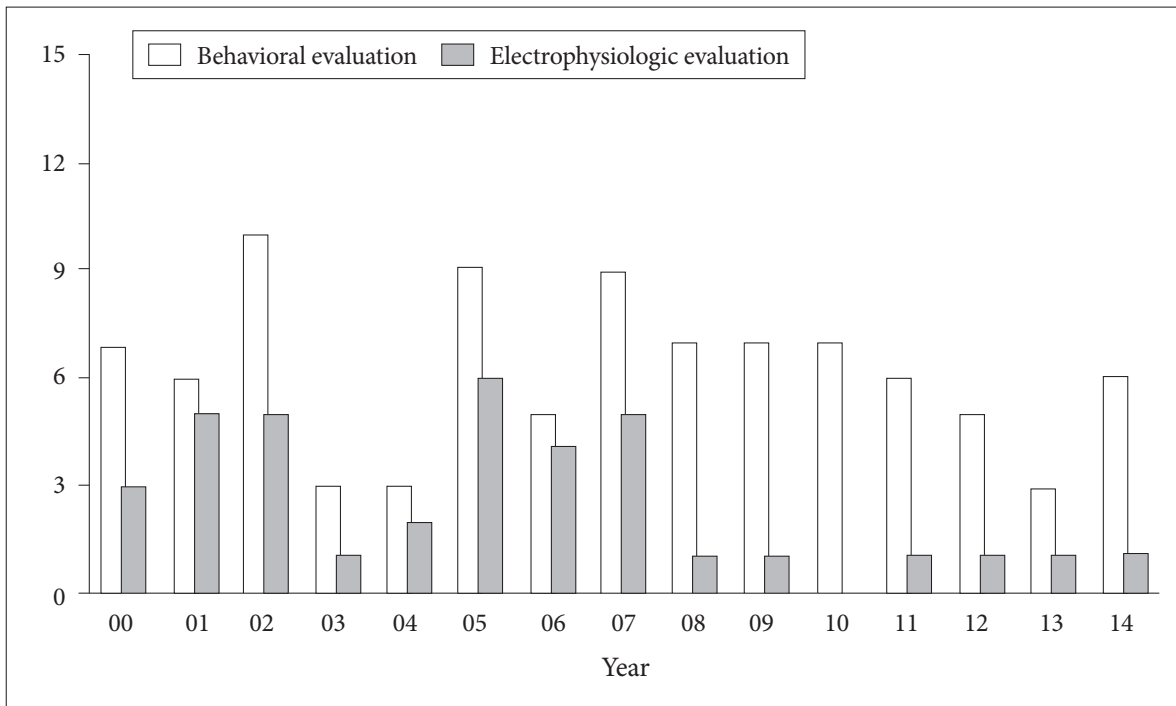

Figure 2. The classification of hearing assessment by year.

인성 난청자의 장애지수를 연구한 논문이 3편으로 그 다음을 차지하였다. 소음성 난청과 관련된 연구는 석-박사 학위논문 총 7편(3.27\%)으로 2009년 첫 발표된 이후로 매년 2편씩 꾸준 히 발표되고 있다. 청능재활에 관한 연구는 5편(2.33\%), 기타 5 편(2.33\%)으로 나타났으며 기타에 포함된 연구의 경우 청각장 애아동의 음운특성, 작업 기억(working memory), 난청시뮬레 이터 소프트웨어 개발 등 다양한 주제에 대해 접근하려는 경 향을 보이고 있다.

증폭기와 관련된 연구주제의 경우 학위논문 총 32편 중 보청 기 적합 및 평가와 관련된 연구는 20편으로 이들 논문은 2005 년까지 총 12 편이 발표되었으나 이후 줄어드는 경향을 보였고 2012 2014년까지 관련 연구가 등장하지 않았다. 반면 인공와 우적합 및 평가 관련 연구는 2009년 이후부터 매년 1 2편씩 지속적으로 발표되었으며 박사학위 논문의 경우 15 편 중 2 편이 인공와우 착용자의 착용효과 및 평가도구 개발을 위한 연구였 다. 중추처리장애 관련 연구는 2004년 첫 논문이 발표된 이후 꾸준히 증가하고 있으며 2011년과 2012년은 전체 23편의 논문 중 9편(39.2\%)이 발표되어 가장 활발한 연구가 이루어진 시기 였다. 이들 연구는 노인성 난청자의 중추청각처리장애에 대한 고찰을 시작으로 중추청각처리장애 선별검사 평가도구의 한국 적용을 위한 도구개발 연구가 주를 이루었다. 청능재활과 이명 에 관한 연구는 2000년 초창기에는 발표되지 않았으나 2006년 첫 편이 발표되었고 2010년부터 매년 지속적으로 발표하고 있 으며 발표 논문도 점차 증가하는 추세이다(Table 4). 전정평가 및 재활에 관한 논문의 경우 2006년 석사 학위논문 2편, 박사 학위논문 1편을 시작으로 2009년에는 총 4편(30.7\%)이 발표되 었고 그 이후 1 2편씩 매년 발표되고 있다. 이들 연구 주제는 석사학위 논문 10편이 전정유발전위(vestibular evoked myogenic potential, VEMP)와 관련되어 VEMP 측정에 따른 변수
의 영향을 보고한 논문 6편, 청력손실에 따른 특성 관련 연구 는 3편으로 주로 평가와 관련된 연구이나 재활효과를 보고한 연구도 1편이 있었다.

\section{연구대상에 따른 분석결과}

실제로 조사된 연구대상의 유형을 분석한 결과는 Table 5 와 같다. 석사 학위논문의 경우 청각장애인을 대상으로 한 연구는 56 편(26.4\%), 청각장애인과 건청인을 비교 분석한 연구 34 편 (16.1\%), 건청인 대상의 연구는 116 편(54.7\%), 기타의 경우 6편 (2.8\%)으로 나타났으며 박사학위 논문의 경우 청각장애인 대상 연구 5편(31.3\%), 청각장애인과 건청인의 비교연구 4편(25\%), 건 청인 대상 연구 7편(43.8\%)으로 석-박사 학위논문에서 비율적 인 차이는 있으나 모두 건청인을 대상으로 한 연구가 많았다. 연구대상의 수는 석·박사 학위논문 공히 50명 이하를 대상으 로 한 연구가 145 편(66.8\%)으로 가장 많았다. 연구대상의 연령 에 따른 분석은 연구대상이 서로 겹치는 경우 각 대상군에 포 함시켜 분석하였으며 그 결과 석사 학위논문의 경우 0 18세 아동 대상자 관련 연구는 44편(17.5\%)이었다(Figure 3). 특히, 영유아 대상 연구의 경우 신생아 대상의 전기생리기능을 이용 한 청능평가 연구 2 편, 신생아에서의 전정유발전위 평가 1편, $0 \sim 28$ 개월 대상 듣기발달의 규준을 연구한 논문 1편, 1 18개월 아동의 발성연구 1편으로 총 5편으로 나타났다. 20 60대 성인 을 대상으로 한 연구는 133편(52.8\%), 65세 이상의 노인을 대상 으로 한 연구는 58 편(23.0\%)이었으며 기타 15편(6.0\%), 부모 혹 은 교사를 대상으로 한 연구는 2편(0.8\%)이었다. 박사 학위논 문의 경우 성인을 대상으로 한 연구는 10편(62.5\%)으로 나타나 석-박사 학위논문 모두 20 60대 성인을 대상으로 한 연구가 143편(69.3\%)으로 가장 많았다. 연구대상의 성별을 분석한 결 과 석·박사 학위논문 전체 228편 중 사람을 대상으로 하지 않 
Table 5. The classification of research subjects $(n=228)$

\begin{tabular}{|c|c|c|c|c|c|c|c|}
\hline Year & Infants and toddlers & Preschoolers & School-aged children & Adults & Elderly people & Parents/teachers & Etc \\
\hline 2000 & & 1 & 1 & 7 & 2 & & 2 \\
\hline 2001 & 1 & 3 & 2 & 5 & 1 & & \\
\hline 2002 & 1 & 4 & 3 & 10 & & & 1 \\
\hline 2003 & & 2 & 3 & 2 & 2 & & \\
\hline 2004 & & & 1 & 4 & 2 & & \\
\hline 2005 & & & 1 & $10(1)$ & 3 & & 2 \\
\hline 2006 & & $1(1)$ & $1(1)$ & $9(1)$ & 6 & & 1 \\
\hline 2007 & & & & 10 & 3 & & \\
\hline 2008 & 1 & & & 11 & 4 & & 2 \\
\hline 2009 & 1 & 1 & 2 & $14(2)$ & 6 & 1 & 1 \\
\hline 2010 & (1) & 1 & 3 & $12(1)$ & $6(1)$ & 1 & 1 \\
\hline 2011 & & 1 & 3 & $12(1)$ & $5(1)$ & & \\
\hline 2012 & 1 & & $1(1)$ & $8(2)$ & 7 & & $2(1)$ \\
\hline 2013 & & & 2 & $8(1)$ & 3 & & 1 \\
\hline 2014 & & 1 & 1 & $10(1)$ & $5(1)$ & & 2 \\
\hline Total (\%) & $5(1.9)$ & $15(6.0)$ & $24(9.5)$ & $133(52.8)$ & $58(23.0)$ & $2(0.8)$ & $15(6.0)$ \\
\hline
\end{tabular}

Parenthesis is the percentage

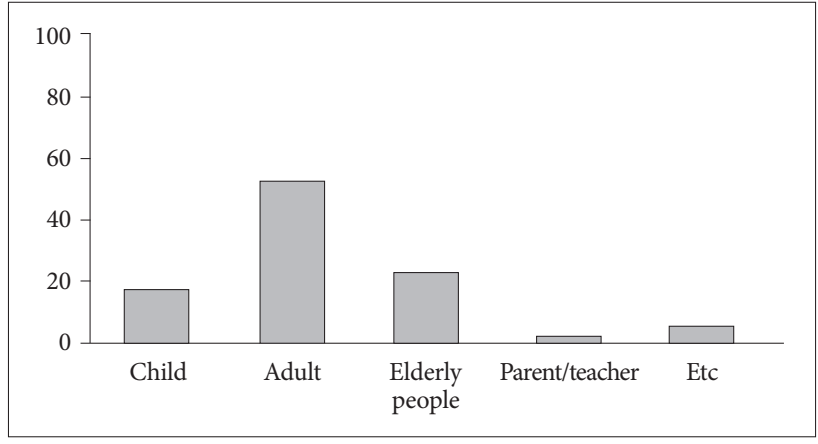

Figure 3. The classification of research subjects.

아 기타의 범주에 포함된 6편(동물 및 마네킹 모델, 인공와우 기계장치, 교실의 신호 대 잡음 연구)과 석사 학위논문에서 성 별에 따른 변수의 영향을 최소화 하고자 여성만을 대상으로 연구한 2편의 연구를 제외하곤 220편 모두 남녀의 비율을 맞 추어 연구한 것으로 나타났다.

\section{DISCUSSIONS}

1997년 청각학이 국내에 소개된 지 20주년을 바라보고 있는 현재 다수의 청각학을 수강할 수 있는 학부와 석·박사 학위과 정이 개설되어있고 이미 상당수는 학위과정을 끝내고 현장에 서 전문가로 일하고 있다. 본 연구는 청각학관련 석·박사 학위 논문을 분석하여 연구동향을 살펴보고 새로운 학문 연구의 방 향에 객관적 정보를 제공하고자 하였다. 이를 위해 박사 학위 논문 16 편과 석사 학위논문 212 편을 선정해 연구방법, 연구유 형, 연구대상에 따라 분석하였고 그 결과에 따라 다음과 같이
논의할 수 있다.

첫째, 1999년부터 2014년까지 청각학으로 취득한 학위논문 은 석사학위 212편, 박사 학위논문 16 편 총 228편으로 논문의 첫 발표 시기는 석사 학위논문의 경우 2000년 13편, 박사 학위 논문은 2015년 1편이 발표되었고 시간의 경과에 따라 증가하 는 경향을 보였다. 연도별 논문편수를 보면 석·박사 학위논문 모두 2009년부터 2012년까지 근소한 차이를 보이며 증가하였 는데 석사 학위논문은 2009년 22편, 박사 학위논문은 2010년 3 편으로 가장 많이 발표되었다. 연도별 이들 논문의 발표편수 는 석사학위과정의 개설과 관련이 있는데 국내의 청각학석사 학위과정은 2001년까지 현 한림국제대학원대학교 한곳이었다. 그러나 2002년 한림대 일반대학원내 학과 간 협동과정을 시작 으로 2003년 세한대(구 대불대) 보건대학원, 2005년 남부대 산 업정책 대학원 그리고 2011년 대구 가톨릭대학교 의료보건과 학대학원에 개설되었다. 따라서 이들 학교에서 졸업생들이 배 출되면서 학위논문이 증가하였으며 2009년의 경우 5개 학교 모 든 대학원과정에서 석사학위 논문이 발표되었으나 학위과정이 개설된 학교에 비해 논문편수는 많지 않다는 것은 고민할 필요 가 있다. 학교별 논문발표 편수를 보면, 한림대 사회복지 대학 원의 경우 67편(29.4\%), 한림대 일반대학원 36편(15.8\%), 한림대 보건대학원 24편(10.5\%), 한림국제대학원대학교 70편(30.7\%), 세한대(구 대불대) 보건대학원 13편(5.7\%) 남부대 정책대학원 2 편(0.8\%), 대구 가톨릭대학교 의료보건과학 대학원에서 2편 $(0.8 \%)$ 이 발표되었다. 한림대를 근간으로 하는 대학원(한림대 사회복지 대학원(1998년) $\rightarrow$ 한림대 보건대학원(2007년) $\rightarrow$ 한림 국제대학원대학교(2009년), 한림대 일반대학원)에서 전체논문 
의 $91.9 \%$ (박사 학위논문의 경우 $100 \%$ 를 발표하고 있고 특정 학교의 응집현상이 두드러져 보인다. 그 외 2003년과 2004년의 경우 석사학위를 취득한 사람의 양적인 증가에 비하여 발표된 학위논문 수는 각각 7편으로 저조하였다. 이와 관련해 추측할 수 있는 것은 일반적으로 논문 발표를 통해 석사학위를 취득 하는 학위과정이 일반적이나 학위취득자격시험에 합격한 경우 에도 석사학위를 취득할 수 있는 특별과정의 기회가 있는데 바 로 이 시기에 특별과정으로 학위를 취득하는 학위자 수가 다수 포함되었기 때문으로 볼 수 있다.

둘째, 연구방법 측면에서 분석해본 결과 석·박사 학위논문 공통으로 실험연구가 가장 많았고 문헌연구는 한편도 나타나 지 않았으나 조사연구와 사례연구도 여러 편 진행되어 연구유 형이 점차 확장되고 있는 것으로 나타났다. 실험연구는 연구자 가 실험에 수동적인 관찰자가 아닌 능동적인 관찰자로 참여하 고 관심 있는 현상을 분리하고 조건을 통제한 실험을 통해 도 출된 결과로서 현상 간의 이해를 목적으로 하기 때문에(Lee et al., 2002) 이러한 실험중재로 나온 경험적 지식은 임상에서 문 제를 합리적으로 해결하는데 있어 인과관계를 분명히 해준다. 따라서 실제 임상현장에서 전문화된 업무를 담당하면서 학업 을 병행하고 있는 사람들에게는 유용하므로 실험연구로 연구 하려는 경향이 강한 것으로 추측할 수 있다. 게다가 청각학의 특성상 청각장애인을 대상으로 특정 보조기기의 효용성을 검 증 하거나 표준화된 평가도구의 검증을 통해 유용성을 도출하 고 임상활용을 위한 학문이므로 계량적 연구가 주를 이루는 자 연스러운 현상으로 보인다. 90년대 이후 청각장애에 대한 수년 간의 연구경향을 보고한 논문에서 석·박사 학위논문의 $47.2 \%$ 가 실험연구로 다른 어떤 연구보다 높았고 그 이유 중 하나를 학위논문이라는 한계성으로 다양한 연구방법의 사용이 제한 되어 있을 것을 추측하였다(Ok, 2005). 본 연구의 경우 일반대 학원 과정에서 발표된 36편의 논문 중 실험연구는 33편(91.7\%), 조사연구는 2 편(5.6\%), 사례연구의 경우 1편(2.8\%)으로 나타나 특수대학원에서 발표된 실험연구 비율 $75 \%$ 보다 상대적으로 높 아 위 저자의 주장으로 추측해 볼 수 있다. 그러나 청각장애와 관련되어 나타나는 여러 가지 문제와 관련지어 대상자의 다양 한 욕구 등을 파악하고 관련 프로그램을 개발하고자 한다면 이들에 대한 이론적 성격의 연구 중심의 학술적 논의가 필요함 에도 불구하고 문헌연구가 한편도 없다는 것은 고민해보아야 할 것이다. 그럼에도 불구하고 사례연구를 통해 상대적으로 중 요한 의미를 찾으려하는 연구가 2010년 노인의 청능훈련 사례 가 발표된 이후 매년 꾸준히 발표되고 있다는 것은 긍정적인 현상이다. 실험연구에 참여하는 연구표본의 경우 대부분 건청 인 대상자들 수준에서 이루어지고 있는데, 이는 건청인을 대상 으로 신뢰도가 검증된 표준화된 새로운 평가 및 재활방법과 전
략을 개발하여 임상현장에서 이용할 수 있는 유용성을 제공할 수 있게 하려는 의도로 파악될 수 있다. 그러므로 단순히 특정 의 방법을 그대로 답습해 적용한 것에서 벗어나 이를 우리나라 실정에 맞는 다양한 방법으로 전환하고자 하는 의도가 있다는 것을 긍정적으로 평가받아야 할 것으로 생각된다.

셋째, 분석대상 논문들의 연구주제에 대한 분석결과 가장 많 은 연구는 청각기능평가(hearing assessment)와 관련된 주제 로 총 93편(43.5\%)이 발표되어 '청각학' 관련 연구경향은 여전 히 청각장애 평가 위주의 논문이 전체 주제의 절반이상을 차지 하고 있다는 것을 알 수 있다. 특히, 어음청력평가에서 어음표 와 관련된 연구는 총 12 편으로 2009년부터 증가하기 시작해 2014년 한해에만 총 3편이 발표되는 등 증가를 엿볼 수 있다. 그 이유는 한국어를 이용한 어음 청각검사 방법이 2009년 12 월 지식경제부(현 산업통상자원부) 국가기술표준원에 의해 한 국산업표준(Korean Industrial Standards)으로 채택되었고 국 제적으로도 국제표준화기구(International Organization for Standardization)와 국제전기기술위원회(International Electrotechnical Commission)의 표준으로 등록되어 국제적으로 도 대한민국의 표준 어음청력검사도구로 인정받게 되었다. 따라 서 이때 개발한 어음인지역치 검사를 위한 이음절어표, 단어인 지도 검사를 위한 단음절어표, 문장검사를 위한 문장표 등을 실 제 임상에서 활용하기 위한 타당성과 신뢰도 검증을 수행하여 보급, 확산을 위한 후속연구가 진행된 것임을 추측할 수 있다. 반 면 전기생리 기능평가의 경우 총 93편 중 36편의 논문이 새롭게 개발된 검사도구 즉, 청성뇌간반응(auditory brainstem response) 검사, 청성지속반응(auditory steady-state response) 검사 등 을 검증하고 활용하기 위한 검사지표를 세우는 연구가 2000년 초반까지 주를 이루었다면 2005년 이후에는 진단검사로서의 의의와 예측도구로서의 유용성 검증, 검사가 어려운 유소아, 혹 은 아동에 보청기 적합(fitting)을 위한 도구(tool) 개발 등으로 범위를 넓히고 있다.

증폭기기와 관련된 연구의 경우 보청기와 관련된 연구는 21 편, 인공와우관련 연구는 11 편으로 보청기와 관련해서 2000년 부터 2005년까지 총 12편(17.4\%)이 발표되었고 2005년 이후 점 차 줄어드는 경향을 보였다. 초기 이들 연구주제는 초창기에는 보청기 착용의 필요성에서 보청기 착용 후 효과검증을 위한 연 구가 주를 이루었다. 인공와우와 관련된 연구의 경우 2009년 이후부터 증가하기 시작하였으며 연구 주제는 인공와우 착용 아동을 대상으로 다양한 청각적 조건에서 청각적 수행력을 보 고하거나, 청각민감도의 변화추이를 관찰하기 위한 청각평가, 청각행동발달평가 위주의 논문이 대부분이었고 향상된 청력을 통해 인지능력의 개선을 확인하기 위한 논문도 다수 보였다. 이 들 연구의 증가는 2000년대 중반까지 청각학이 전자공학이나 
의료기술의 발달로 인해 인공와우 및 보청기 등 보조공학의 활 용에 관심을 보였기 때문으로 추측할 수 있다. 그러나 2005년 인공와우 이식에 대한 의료보험의 적용으로 시술대상자가 증 가하였고 인공와우를 착용한 청각장애인들이 듣기를 활용해 구화를 통한 의사소통의 가능성이 높아지면서 기계적인 장치 에 걸맞은 체계적인 훈련프로그램의 필요성 및 활용의 긍정적 성과는 청능재활과 언어발달 측면에서 연구의 증가를 이끌었 다. 추후 언어 및 청능발달과 관련된 재활치료적 접근에 국한 되지 않고 인공와우 착용 아동의 사회·정서 발달에 대한 연구, 학업수행력 성취를 위한 교육프로그램 개발에 대한 연구 또한 이루어져야 할 것이다. 게다가 인공와우 이식대상자 범위가 65 세 이상의 노인까지 확대되면서 노인층에서 이식이 증가하고 있는 현 추세에서 인공와우 착용 성인을 위한 표준화된 청능재 활 프로그램 개발 및 인공와우 기기와 관련하여 어음처리평가 및 알고리즘 분석 등 공학적인 분야의 연구 또한 진행되기를 기 대한다.

청각관리 분야의 경우 총 15편(17.1\%)의 학위논문이 발표되었 는데 청능평가 도구개발에 관한 연구가 총 7편으로 어음평가도 구 개발과 관련된 연구들이 주를 이루고 그 외 아동들의 듣기 발달평가, 노인성 난청 장애지수 개발 등 도구개발에 대한 연구 가 이루어졌다. 그러나 청능평가 도구개발에 관한 연구는 2012 년 이후 나타나지 않고 있다.

중추청각처리장애의 평가 및 재활에 관련된 논문의 경우 2004년 첫 논문이 발표된 후 매년 1 2편씩 발표되어 총 22편 (10.4\%)이었으며 2011년과 2012년의 경우 2년 동안 총 9편(41\%) 이 발표되었다. 특히, 2012년은 3편의 박사 학위논문 중 2편이 중추청각처리장애 진단을 위한 주관적인 검사방법과 관련된 주제였다. 이처럼 이 시기에 발표논문이 많은 이유는 중추청각 처리를 조기에 선별하여 적절한 재활 및 교육을 제공하여 영향 을 최소화하고자 청각행동특성에 대한 정보를 제공하는 체크 리스트(behavioral checklist) 및 질문지(questionnaire) 등의 검 사 도구들의 개발이 2010년에 시작되었고 2012년 표준화된 '청 각행동특성 검사 도구(KNISE-Auditory Behavioral Checklist)가 편찬되었다. 따라서 이 시기에 연구자로 참여한 주체자들 이 실제 임상활용을 위한 신뢰성 및 타당성검증 등 후속연구를 진행하였기 때문으로 볼 수 있다. 특히 중추처리장애는 청각 언 어만의 문제에서 벗어나 다른 장애와 동반되어 문제를 야기할 수 있어 조기판별 및 진단이 중요하다. 따라서 이와 관련된 연 구는 긍정적인 평가를 받고 있으나 중추처리장애를 선별한 뒤 청각처리특성과 이에 따른 재활프로그램의 개발과 재활계획에 대한 정보를 적용할 수 있는 연구가 함께 진행되어야 할 것이다.

이명은 현대 사회에서 소음의 증가, 복잡해지는 정신생활, 노 령 인구의 증가, 약물의 남용, 스트레스 등으로 신체에 미치는
영향들이 증가하고 있는 추세로(Park et al., 2003), 안타깝게도 성인뿐만 아니라 초등학생의 절반(46.9\%) 그리고 청소년의 75\%가 일시적 이명을 경험한다고 보고하고 있다(Kim, 2012). 그러나 병태 생리가 완전히 밝혀지지 않았고, 치료 및 처치에 있어서 한계가 있어 많은 연구가 이루어지고 있는 분야이지만 특수한 상황에서 근무하는 군인 등 의무복무자들의 이명에 대 한 연구는 더욱 더 미비한 편이다. 이와 관련해 군 복무 중 발 생하는 다빈도 질환은 미국의 경우 이명과 난청이 $15 \%$ 이상의 점유비를 보이며 국내의 경우 이명으로 국가보훈처에 유공신청 을 한 건수가 2004년 86건에서 2009년 779건에 달하고 있다'고 보고(Lee et al., 2011) 되어 많은 관심과 연구가 이루어져야 할 분야이다. 이와 관련한 청각학 학위 논문의 경우 2006년 첫 논 문이 발표되었고 한동안 등장하지 않다가 2009년에 다시 연구 되기 시작하였으며 매년 2편 이상씩 꾸준히 발표되고 있다. 특 히 전군역자를 대상으로 이명과 우울증의 원인을 밝히고 삶의 질을 향상시키고자 한 연구 및 삶의 질에 관한 연구가 이루어졌 다. 이명에 대한 명확한 검사법이 고안되지 않아 피검자의 주관 적 의사표현에 의존해야 하므로 객관적 검사방법의 필요성이 강조되어 왔는데 Turner et al.(2006)은 동물모델의 객관적 이명 검사 방법인 gap pre-pulse inhibition of acoustic startle로 이 명현상에 대한 객관적 판단 가능성을 높임에 따라 의과분야에 서 이에 대한 체계적인 연구가 진행 중이다(Jeon et al., 2013; Lobarinas et al., 2013). 그러나 본 학위논문들 대부분의 연구 는 아직까지는 이명장애지수(analysis of factors affecting tinnitus handicap inventory)를 이용한 이명의 주관적 평가를 시 도한 연구가 특히 많았으나 acoustic change complex의 유발 되는 기전을 이용해 객관적으로 이명을 평가하고자 하는 시도 도 보이고 있다. 게다가 이명훈련의 성과를 보고하거나 동물모 델을 통해 이명의 메커니즘을 알아보고자 한 연구까지 그 주제 가 아주 다양해지고 있음을 알 수 있다. 특히 이명에 대한 치료 법이 없고, 보청기와 같은 현재의 치료법으로 다수의 환자들에 게 안도감을 주지 못하는 상황에서 동물모델을 통해 그 잠재적 인 원인을 확인한다면 효과적인 처치법이 개발될 수 있다는 가 능성이 보이므로 동물모델을 통해 이명의 메커니즘을 분석하 고자 한 논문은(Park, 2012) 상당히 값진 연구라 할 수 있다. 추후 청력손실에 중점을 둔 캠페인을 통해 일시적 이명 증상이 영구적인 증상이 될 수 있음을 강조하는 교육프로그램의 개발 에 관한 연구로 확장될 수 있기를 바래본다.

소음은 공장의 기계소음 외에 일상생활에서의 소음은 현대 인들에게 삶의 질을 저하하고 건강을 위협하는 심각한 사회문 제가 되고 있다. 문헌에 따르면 전인구의 $1.7 \%$ 가 소음성 난청에 의한 장애를 가지고 있고(Phaneuf \& Hetu, 1990) 미국의 경우 약 1,000 만 명의 소음성 난청 환자가 있다고 보고하고 있다 
(Brink et al., 2002). 따라서 소음노출에 대한 프로그램의 개발, 청력손실을 예방하기 위한 중재프로그램의 적용 등이 시급한 실정이다. 이러한 현상에 청각학 전공자들은 2006부터 소음성 난청과 관련된 연구를 꾸준히 진행시키고 있는 현상은 시대의 요구에 부응한 좋은 본보기라고 할 수 있다. 이들 연구주제 대 부분은 건청인 혹은 보청기나 인공와우 착용자를 대상으로 배 경소음에서 말소리를 구분하는 능력을 향상시키기 위한 기초 연구로 수용소음레벨(acceptable noise level)을 측정하고 이를 근거로 보청기의 보조기의 만족도를 평가한 연구였다. 또한 교 실소음 속에서의 환경음 인지 연구, 국철 실내 소음패턴 분석, 군전역자의 이명에 대한 연구 등 그 주제범위가 학위논문의 한 계에 따른 특정범위에서 그치지 않고 사회 전반에 걸친 문제까 지 인식하고 있음을 엿볼 수 있다. 추후 소음으로 건강에 어떤 영향을 주는지 주·객관적 평가도구의 개발과 소음에 의한 부 정적 영향을 최소화하기 위한 방안이 연구되어야 할 것이다.

전정기능의 평가 및 재활에 관한 연구는 2006년 석·박사 학 위논문이 동시에 발표된 시점을 계기로 매년 1 3편씩 꾸준히 발표되었으나 2012년 이후는 등장하지 않고 있다. 이들 학위논 문의 연구 주제는 새로 개발된 전정기능평가도구인 전정유발근 전위의 양호도 검증을 위한 각 관련 변인들의 영향력이 통계적 으로 유의한지 연구한 논문이 대부분이었다. 노인인구에서 나 타나는 질병에 대한 대책은 이들의 삶의 질을 향상시킬 수 있 어 노인문제를 해결할 수 있는 하나의 대책이 될 수 있을 것이 다. 그러므로 75세 이상의 노인이 가장 흔하게 호소하는 증상 중 하나인 어지럼증에 대한 실제 사례를 통한 임상데이타의 분 석과 검사방법의 표준화 작업 그리고 재활에 대한 개별화된 프 로그램 개발 등이 선행된다면 청각학의 학문 분야를 한층 더 확장시킬 수 있을 것이다.

넷째, 연구대상에 따른 분석의 경우 연구대상의 수는 석·박 사 학위논문 공히 50명 이하를 대상으로 한 연구가 145 편 (68.4\%)이며 석사 학위논문의 경우 10명 이하를 대상으로 한 연구는 19편(9.0\%), 100명 이상을 대상으로 한 연구는 25편 (11.8\%)으로 나타났다. 설문지를 통한 조사연구의 경우 연구대 상은 평균 $430 \pm 96.8$ 명 그리고 사례연구의 경우 $17.8 \pm 6.3$ 명 으로 신뢰수준 $95 \%$ 에서 검증을 기준으로 표본수를 정한 것으 로 최대허용오차를 따랐으며(Lee et al., 2013) 연구의 정당성을 뒷받침할 수 있는 표본수를 맞춘 것으로 사료된다. 난청인과 건 청인으로 대상자를 나누어 분류하여 분석했을 때 청각장애인 대상 연구는 60편(27.1\%)으로 노인과 성인 난청인의 대상비율 이 높았으며 건청인 대상 연구는 109편(49.3\%), 건청인을 대조 군으로 청각장애인을 대상군으로 한 연구는 46편(20.5), 기타의 경우 6편(2.7\%)로 나타났다. 기타에 포함된 대상은 동물모델 및 마네킹 모델, 인공와우 장치, 교실의 신호 대 잡음 연구, 난청시
물레이션 소프트웨어 연구가 있다.

연구대상자의 연령별 분석결과 가장 많이 연구된 대상은 20 60대 성인으로 석·박사 학위논문 총 143편(52.8\%)이었고 65세 이상의 노인을 대상으로 한 연구는 58 편(23.0\%), 그리고 아동 대상 연구는 44편(17.5\%) 부모 혹은 교사를 대상으로 한 연구는 2편(0.8\%)으로 청각학 석·박사 학위논문 모두 20 60 대 성인을 대상으로 한 연구가 많았다. 반면 국내 청각장애 관 련 학위논문에서 $\mathrm{Ok}(2005)$ 은 아동기, 학령기아동을 대상으로 한 연구가 $82.4 \%$ 라고 보고하였는데 이들 연구저자의 경우 교육 대학원과 특수대학원을 다니며 현장에서 직접 청각장애 아동 을 교육하고 있는 언어치료사 혹은 특수교사를 주체로 삼은 이 유이다. 그러나 본 학위논문 저자들의 경우 청각학을 석·박사 로 전공하고 병원, 혹은 임상센터를 근거로 청력평가 및 보청기 적합과 그리고 청능재활을 업무로 하고 있는 사람이 대부분이 다. 따라서 자신의 업무와 관련 있는 대상층을 연구대상자로 삼은 까닭에 성인 및 노인 대상 연구가 많다고 할 수 있다. 그러 나 2009년 장애아동 재활치료 바우처 사업이 시행됨에 따라 언어, 미술, 음악, 행동·놀이, 심리, 감각·운동, 청능 등의 발달 재활 서비스가 제공되었다. 따라서 청능재활 서비스에 대한 수 요의 증가는 아동의 청능재활에 참여하는 청능사의 증가를 예 측할 수 있으므로 추후 아동을 대상으로 한 연구도 증가할 것 으로 보인다.

영유아를 포함한 학령전기 및 학령기 아동에 대한 연구는 총 44편(17.5\%)으로 나타났는데 이 중 3세 미만 영유아 대상 연구의 경우 5편(11.3\%), 중·고등학교 청소년을 대상으로 한 연 구는 4편(9\%)으로 특정 연령층 중심의 연구가 이루어지고 있음 을 알 수 있다. 일반적으로 청소년층은 스마트폰이나 MP3를 비 롯해 휴대용 멀티미디어플레이어(portable multimedia player), 플레이 스테이션 포터블(play station portable) 등 다양한 디지 털 첨단기기 사용에 노출될 가능성이 높고 이로 인해 잠재적인 청력손실의 가능성이 있다. 미국의 경우 6 19세 사이의 아동. 청소년 $12.5 \%$ 가 소음성 증상을 보이며 대학생에서도 $15 \%$ 가 청 력손실을 호소하고 있다(Vogel et al., 2009). 국내의 경우 10대 청소년 청력손실 환자의 비율은 최근 5년간 $30 \%$ 로 증가하고 있어(Hong et al., 2013; Kwak \& Kim, 2012) 동·서양을 막론 하고 디지털기기로 인한 피해는 적지 않다는 것을 보여준다. 이 런 점에서 한창 성장기에 있는 청소년들의 청력보호에 각별한 주의가 필요한데 고등학생 이어폰 사용실태와 청력수준을 조 사한 연구(Choi et al., 2000; Park, 2001; Park \& Kim, 2001) 는 15년 전에 이미 청소년들의 청력손실 가능성에 대한 문제를 인식하고 있었음을 알 수 있다. 특히 청력손실과 의학, 한의학, 간호학, 언어병리학 등 청각학 인접 학문의 연구도 활발히 진 행 중으로(Kim et al., 2011; Kwak \& Kim, 2012; Lim et al., 
2001; Lindberg et al., 1984) 청각학 전공 석사 학위논문에서 는 개인음향기 사용실태와 청력상태, 이명장애지수의 관련성 연구, 헤드폰 종류에 따른 음압강도 분석에 대한 연구 등은 소 음성 난창의 문제인식과 함께 소음성 난청의 예방자료로 제공 하고자 한 의도로 보인다. 추후 청소년 청력손실 선별검사의 일 환으로 학교청력검사에 대한 조사 그리고 문제제기와 개편 방 안 등에 대한 심도 있는 연구가 이루어진다면 이들이 난청으로 개인의 삶의 질뿐만 아니라 직업의 선택 및 사회생활에서 문제 가 될 수 있는 요인을 줄여나갈 수 있을 것으로 사료된다.

노인층을 대상으로 한 연구는 58편(23.0\%)으로 매년 일정비 율을 유지하고 있으며 최근 연구비율이 점차 높아지고 있는 추 세인데 이는 사회적으로 인구의 노령화로 인한 청력손실에 대 한 관심이 여전히 높은 까닭으로 보인다. 연구주제는 노인들의 청력실태에 대한 조사에서부터 노인성 난청 선별을 위한 장애 지수 개발연구, 이들의 어음지각의 어려움 특히, 노화에 의한 중추처리능력의 제한으로 듣기의 어려움에 대한 진지한 연구 를 통해 보청기를 착용을 시도하고 그 효과를 검증하고자 한 연구 그리고 청능훈련을 통해 어음인지력의 향상을 보고한 논 문들이 주를 이루었다. 또한 노인들의 우울성향에 대한 연구, 청능재활 프로그램에 대한 수요조사까지 진행되어 있어 노인성 난청에 대한 연구의 폭이 평가-진단-재활뿐만 아니라 삶의 질 을 향상시키기 위한 노력까지 접근하려는 경향을 보였다. 특히 2020년 전체 인구의 $16 \%$ 인 800 만 명이 노인인구로 채워지며 노인성 난청 환자 수 또한 200만 명을 넘어설 것으로 예상되는 초고령화 국가인 우리나라는 노인성 난청에 대한 현실적인 대 책이 시급한 실정이다. 따라서 이들의 청각서비스를 책임지고 있는 전문가들의 노력이 청력손실에 대한 조기 발견 및 예방, 그리고 재활과 관련된 연구는 노인의 삶의 질 향상 및 자립능력 의 향상을 통해 노인의 사회 참여를 확대하여 개인적인 차원뿐 아니라 사회적인 통합을 기대할 수 있는 시스템을 만들 수 있는 초석이 될 것으로 기대된다. 특히, 청각장애 아동의 정체성을 결 정짓는 것은 단순히 청능 혹은 언어발달의 향상에만 있지는 않 다. 청각장애 아동의 경우 학교에서의 부정적인 경험이 이들의 정서 및 행동에 영향을 미치는 바 적극적 중재자로서 부모와 교 사의 역할이 중요하다고 할 수 있다. 따라서 아동의 특성을 파 악하고 부모나 교사들이 어떻게 이들을 적절히 도와주어야 하 는지가 매우 중요함에도 불구하고 부모, 교사들을 대상으로 한 연구는 단지 2편(0.8\%)에 불과하다. 그러나 2009년 발달재활바 우처 제도의 시행으로 청각장애 아동의 청능재활에 참여하는 청능사의 수요가 증가하고 있어 연구대상의 범위가 확장될 수 있는 가능성을 기대해본다.

본 연구는 1999 2014년 청각학 전공 학위논문 228편을 분 석하여 연구동향을 살펴보고 연구 문제점을 분석하여 향후 연
구 과제를 제시하고자 하였으나 질적인 접근보다는 형태적이고 계량적인 측면에서 접근하였으므로 동향분석의 보편성 보장에 한계가 있을 수 있다. 그럼에도 불구하고 국내 석·박사 학위논 문을 분석하여 청각학의 연구동향을 종합적으로 제시하였다 는 데 그 의의가 있으며 이와 같은 결과와 논의를 통하여 얻어 진 결론은 다음과 같다.

첫째 청각학 관련 연구방법 측면에서 실험연구 조사연구 사 례연구 순서로 연구가 이루어졌으며 실험연구 비율이 83.3\%로 가장 높았다. 실험연구가 높게 나타난 것은 이론이 점차 우리나 라 실정에 맞도록 적용된다는 것을 의미하나 대부분의 연구가 건청인 기준에서 이루어지고 있다는 것은 부정할 수 없다.

둘째 연구대상에 따른 분석결과에서 20 60대 성인층을 대 상으로 한 연구가 $69.3 \%$ 로 대부분을 차지하고 있으며 그 대부 분이 실험연구였다.

셋째 연구주제에서는 청각장애인에 대한 학문적인 접근에서 부터 진단·평가, 보조기 처방·적합, 재활까지 체계적으로 연구 되고 있음을 알 수 있다. 또한 빠르게 변화하는 시대적 흐름을 파악하고 그에 맞는 연구를 진행하고 있어 미래지향적인 학문 의 경향을 보여주고 있었다. 그러나 여전히 청각장애 평가 위주 의 논문이 전체 주제의 절반 이상을 차지하고 있다는 것은 고 민해야 할 현안이기도 하다. 이상의 결과를 기초로 향후 질 높 은 연구를 확충하기 위해 다음을 제안할 수 있다.

첫째, 본 연구는 대상논문 수가 많은 이유로 계량적인 분석 을 통해 종합적인 분석만을 수행하였으므로 추후 연구주제를 중심으로 한 질적 분석이 필요하다.

둘째, 난청인을 위한 중재전략에 대한 연구가 필요할 것으로 사료된다. 특히 연령에 따른 중재특성별 효율적인 중재프로그 램의 개발과 검증하는 실험연구, 그리고 개발된 중재프로그램 적용에 대한 연구가 이루어질 필요가 있다.

셋째, 본 연구는 석·박사 학위논문만을 분석한 자료로 실제 현장에서 제기되는 문제가 무엇인지 연구방향과 연계된 객관적 인 정보를 얻기 위해서는 청각학 국내 학술지 분석이 심층적으 로 이루어질 필요가 있다.

넷째, 난청인의 사회·심리적 특성에 맞춘 총체적 재활 측면 에서 자아 존중감을 향상시켜 삶의 질을 높일 수 있는 변인으 로서의 연구가 필요하다.

다섯째, 다학문적인 접근에서 청각학 및 인접학문과 연계한 다양한 주제의 논문을 통해 동반발전이 되는 연구가 필요할 것 으로 본다.

중심 단어 : 청각학·연구동향·연구방법. 


\section{REFERENCES}

American Speech-Language-Hearing Association (ASHA). (2015). Scope of Practice in Audiology. Retrieved from http://www.asha.org/policy/ SP2004-00192/.

Brink, L. L., Talbott, E. O., Burks, J. A., \& Palmer, C. V. (2002). Changes over time in audiometric thresholds in a group of automobile stamping and assembly workers with a hearing conservation program. American Industrial Hygiene Association Journal, 63(4), 482-487.

Choi, S. H., Ko, D. H., \& Lee, J. H. (2000). The study on the high school students' use of earphone and the evaluation of their hearing level. Communication Sciences and Disorders. 5(1), 1-19.

Gelfand, S. (2009). Essentials of Audiology. (3rd ed.). New York, NY: Thieme.

Goulios, H. (2010). Comparative audiology and the development of a seeding model for affordable and sustainable audiology education (unpublished master's thesis). The University of Western Australia, Western Australia.

Hong, H. N., Kang, T. H., \& Hong, B. N. (2013). Survey on the use of MP3 players of high school students and the effect to their hearing thresholds. The Journal of the Acoustical Society of Korea, 32(1), 56-63.

Jeon, P., Jung, J. Y., Lee, S. H., \& Park, I. (2013). An implementation of a GPIAS measurement system for animal tinnitus detection and study on effect of starting point of stimulus background sound on startle response. Journal of Sensor Science and Technology, 22(6), 410-414.

Katz, J. (2002). Handbook of Clinical Audiology. (4th ed.). Baltimore, MD: Williams and Wilkins.

Kim, U. B. (2000). Trend of researches for communication disorder (unpublished master's thesis). Dankook University, Yongin.

Kim, K. W., Jung, J. Y., \& Suh, M. W. (2011). Effects of earphone style and noise environment on listening levels when using portable music players in the laboratory. Communication Sciences and Disorders, 16(3), 408-415.

Kim, S. H., Lee, Y. H., Hwang, J. H., \& Oh, M. E. (2014). Census bureau, disability status in 2014. Korea Institute for Health and social affairs. $1-640$.

Kim, Y. H. (2012, June 29). Elementary school students reported that they were experiencing tinnitus. Doctors news. Retrieved from http://www. doctorsnews.co.kr/news/articleView.html?idxno $=80182$.

International Organization for Standardization (ISO). (2012). Acousticsaudiometric test methods-Part 3: Speech audiometry. KSI ISO 8253-3. Seoul: Korean Agency for Technology and Standards.

Korean Agency for Technology and Standards. (2009). Acoustics-audiometric test methods-Part 3: Speech audiometry. KSI ISO 8253-3. Seoul: Korean Agency for Technology and Standards.

Kwak, H. W. \& Kim, N. H. (2012). Study on relations among use of earphones, stress, and hearing threshold in university students. Journal of Korean Public Health Nursing, 26(1), 126-136.

Lee, H. J., Kim, Y. S., \& Park, I. (2013). Calculation of sample size in clinical trials. Clinics in Shoulder and Elbow, 16(1), 53-57.

Lee, H. S., Ok, J. D., \& Kim, B. H. (2004). An analytic review of research papers related to hearing disorders in Korea. The Journal of Special Education: Theory and Practice, 5(3), 181-202.
Lee, S. H. (1999). Division of speech pathology and audiology. Communication Sciences and Disorders, 4, 5-15.

Lee, S. H., Kim, K. S., Choi, U. H., \& Kim, J. S. (2011). Guidelines for the assessment of general damages in personal injury cases: Hearing loss · tinnitus. Ministry of Patriots and Veterans Affairs, 1-385.

Lee, T. W., Kim, C. J., Park, J. S., \& Kim, S. S. (2002). Nurse's adoption on a planned organizational change. Journal of Korean Academy of Nursing, 32(2), 155-164.

Lim, H. W. \& Chae, S. W. (2011). The current state of age-related hearing loss in South Korea. Journal of the Korean Medical Association, 54(9), 910-917.

Lim, K. H., Park, K. M., \& Park, M. H. (2001). A study about the factors affecting hearing loss in adolescent's use of personal cassette players (PCPs). Journal of Korean Community Nursing, 12(1), 125-141.

Lindberg, P., Lyttkens, L., Melin, L., \& Scott, B. (1984). Tinnitus-incidence and handicap. Scandinavian Audiology, 13(4), 287-291.

Lobarinas, E., Hayes, S. H., \& Allman, B. L. (2013). The gap-startle paradigm for tinnitus screening in animal models: Limitations and optimization. Hearing Research, 295, 150-160.

Martin, F. N. \& Clark, J. G. (2003). Introduction to Audiology. Boston, MA: Allyn and Bacon.

Newby, H. A. \& Popelka, G. R. (1992). Audiology. (6th ed.). Englewood Cliff, NJ: Prentice-Hall.

Ok, J. D. (2005). An analysis of dissertations related to hearing impairment: Focusing on the graduation schools of education in Korea. Journal of Special Education: Theory and Practice, 6(1), 37-55.

Park, H, J. (2000). Study on the high school students' hearing level (unpublished master's thesis). Hallym University, Chuncheon.

Park, M. O., Kim, J. S., \& Shin, J. S. (2003). Relationship between the discomfort of tinnitus and the quality of life in tinnitus patients. The Korean Journal of Rehabilitation Nursing, 6(1), 40-50.

Park, S. H. \& Kim, J. M. (2001). Analysis of the journals of communication disorders and language teaching-method. Communication Disorder, 24(3), 195-210.

Park, S. J. (2012). Development and validation of tinnitus animal model (unpublished master's thesis). Nambu University, Gwangju.

Phaneuf, R. \& Hetu, R. (1990). An epidemiological perspective of the causes of hearing loss among industrial workers. The Journal of Otolaryngology, 19(1), 31-40

Seong, T. J. (1998). Introduction of Educational Research Methods. Seoul: Hakjisa.

Song, C. Y. \& Park, B. K. (2011). The Issues and Policy Challenges of Aging Society. Seoul: Korean Research Institute for Vocational Education and Training.

Turner, J. G., Brozoski, T. J., Bauer, C. A., Parrish, J. L., Myers, K., Hughes, L. F., et al. (2006). Gap detection deficits in rats with tinnitus: A potential novel screening tool. Behavioral Neuroscience, 120(1), 188.

Vogel, I., Brug, J., van der Ploeg, C. P., \& Raat, H. (2009). Strategies for the prevention of MP3-induced hearing loss among adolescents: Expert opinions from a Delphi study. Pediatrics, 123(5), 1257-1262. 